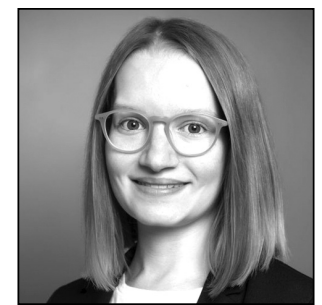

Selina Domhan

\title{
Online Hearings in Proceedings before International Commercial Courts
}

\section{Introduction}

Over the last six years, several jurisdictions, across Europe, have established international commercial courts or chambers for international commercial matters. This article focuses on the possibility of online hearings via videoconferencing in proceedings before international commercial courts in Europe. The possibility of using video technologies enables the lawyers, parties, and witnesses to follow the proceedings from different locations and, accordingly, saves time and money on otherwise necessary travel. In these times of the COVID-19 pandemic, the topic is more relevant than ever.

For this purpose, the article provides a brief descriptive overview of the key features of the international commercial courts and chambers in Europe, including the possibilities for using communications technology to conduct online proceedings. Based on these findings, the current measures and developments in the context of the coronavirus pandemic are described. Furthermore, opportunities for using videoconferencing techniques in the context of the cross-border taking of evidence are discussed, with the relevant portion of the paper focusing on the EU Regulation on cooperation between the courts of the member states in the taking of evidence. The final part deals with the question of whether the recast of that regulation is going to simplify the cross-border taking of evidence by means of videoconferencing in practice.

\section{International commercial courts in Europe}

Notwithstanding the fact that there is no universally accepted definition for an international commercial court, some characteristics can be identified: The international commercial courts and chambers presented in the following discussion are, in fact, national courts or chambers and therefore part of their national court systems that express an international dimension by dealing with the settlement of international commercial disputes. As much as they differ in their details, they all have in common that they combine elements of traditional court litigation and arbitration - in particular, through the introduction of English as the language of proceedings, in order to increase the attractiveness of the respective domestic civil-justice systems. For this reason, the Commercial Court of England in Wales, located in London and established already in 1895 , is not considered in this article. Rather, the focus is on the newly established chambers and courts in Germany, France, and the Netherlands.

1 This article is based on my PhD thesis, defended in July 2021. 


\subsection{Germany}

\subsubsection{Projects in several German states}

In 2010, several district courts in the German state of North Rhine-Westphalia started a model project and established special international chambers offering the parties the option of choosing English as the language of the oral proceedings. The conditions for the jurisdiction of these special chambers were the existence of a corresponding agreement between the parties, a waiver of the right to an interpreter, and an international connection of the facts. ${ }^{{ }_{2}}$ This option has hardly ever been used in practice. ${ }^{*} 3$

In 2016, the 'Justice Initiative Frankfurt' was launched, under the leadership of Burkhard Hess, Thomas Pfeiffer, Christian Duve, and Roman Poseck, with the aim of strengthening the attractiveness of Frankfurt as a dispute-resolution centre. ${ }^{*}{ }^{4} \mathrm{~A}$ combination of various measures was envisaged, particularly the provision of a well-equipped court and experienced judges with good language skills coupled with a modern process design to enable a practical, user-friendly framework for the settlement of international commercial disputes. ${ }^{*} 5$

In the implementation of these proposals, an English-speaking chamber was established within the Frankfurt am Main District Court in early 2018. ${ }^{*}$ This chamber is composed of one professional judge (as presiding judge) and two honorary judges as so-called commercial judges. The chamber is competent for the settlement of international commercial disputes under the following conditions: it has jurisdiction if the case pertains to an international commercial matter, and, in addition, before the deadline for the statement of defence passes, the parties have to declare that they would like to plead in English during the oral hearings and waive the right to have an interpreter. ${ }^{*}$ There are no additional court fees for proceedings before this chamber.

Since 1 May 2018, the Hamburg District Court too has offered the option of hearing cases in English with regard to civil law cases in the areas of private international law, patent and trademark law, as well as for disputes unfair competition law, by mutual consent of the parties. ${ }^{* 8}$

In November 2020, the German state of Baden-Württemberg established two (on-demand) Englishspeaking commercial courts as part of the district courts of Mannheim and Stuttgart. ${ }^{*}$ In contrast to the chamber at the district court of Frankfurt, the parties may choose whether to have their case heard by the civil chamber with its three professional judges or, alternatively, by the chamber for commercial matters, comprising one professional judge and two commercial judges. ${ }^{{ }^{*} 0}$ The commercial court in Stuttgart is competent for disputes in connection with the acquisition of companies or shares of companies, disputes resulting from mutual commercial transactions with a value in dispute of at least $€ 2$ million, and corporates disputes. ${ }^{* 11}$ The jurisdiction of the Mannheim Commercial Court is very similar but is restricted in that it is competent only for hearing disputes with a value in dispute of at least $€ 2$ million. ${ }^{* 12}$ Both courts are staffed with highly qualified and experienced judges who possess excellent skills in the English language. ${ }^{* 13}$

2 Johannes Riedel, 'Englisch als Verhandlungssprache vor Gericht' in Mathias Habersack and others (eds), Festschrift für Eberhard Stilz zum 65. Geburtstag (C.H. Beck 2014) 502.

3 Christoph A Kern and Georg Dalitz, 'Netherlands Commercial Court und Maritieme Kamer - Englisch als Verfahrenssprache in den Niederlanden' (2016) 21 ZZPInt 119, 121; Riedel (n 2) 503.

4 Burkhard Hess, 'The Justice Initiative Frankfurt am Main 2017' (31 March 2017) <https://conflictoflaws.net/2017/thejustice-initiative-frankfurt-am-main-2017-law-made-in-frankfurt/> accessed 15 July 2021.

5 Ibid.

6 'Chamber for International Commercial Disputes'<https://ordentliche-gerichtsbarkeit.hessen.de/ordentliche-gerichte/ lgb-frankfurt-am-main/lg-frankfurt-am-main/chamber-international> accessed 15 July 2021.

7 Ibid.

8 'LG Hamburg Zuständigkeiten' <https://justiz.hamburg.de/landgericht-hamburg/zustaendigkeit/> accessed 15 July 2021.

9 'Commercial Court' < www.commercial-court.de/en/> accessed 15 July 2021; see also Patrick Melin, 'Der neue Stuttgart Commercial Court: - eine Antwort auf die Herausforderung, internationale Wirtschaftsrechtsstreitigkeiten vor staatliche Gerichte zu bringen -' [2020] BB 2702.

10 'Commercial Court - Sites'<www.commercial-court.de/en/sites> accessed 15 July 2021.

11 Ibid.

12 Ibid.

13 'Commercial Court' (n 9). 


\subsubsection{Legislative proposals}

Of course, the establishment of commercial courts or chambers for international commercial matters is only a first step toward attracting more economically significant international proceedings to Germany. In addition, there has been discussion of a draft bill providing for the possibility of using the English language without limitation in court proceedings. ${ }^{{ }^{14}}$

Section 184 of the German Courts Constitution Act (GVG) states that the language of the court shall be German. Exceptions to this are permitted only within strict limits. Section 185 (1) provides that an interpreter shall be called in if persons are participating in the hearing who do not have a command of the German language. In accordance with section 185 (2) an interpreter may be dispensed with if all the persons involved have a command of the foreign language used.

Only under a broad interpretation of section 185 (2) of the GVG, which the projects presented just above make use of, is it possible at all to conduct some steps of the procedures in English. ${ }^{* 15}$ This possibility is essentially limited to the oral hearing and the submission of documents, while judgements and other court decisions, along with the minutes of the proceedings, must be delivered in German. ${ }^{*} 16$ In light of the requirements of the German GVG, therefore, only a few procedural steps may actually be carried out in English.

Against this backdrop, corresponding amendment to the above-mentioned provisions of the GVG, particularly its Section 184, is necessary, as provided for in the draft bill on the introduction of Chambers for International Commercial Matters, which has already been introduced on two occasions, in $2010^{* 17}$ and $2014^{* 18}$, but proved unsuccessful. The prospect of Brexit gave additional impetus to revival of plans to introduce English as an optional court language. In February 2018, the draft was again introduced. It remains to be seen whether this time it is going to be successful.

\subsubsection{The possibility of online hearings}

Section 128a of the German Code of Civil Procedure (ZPO) allows oral hearings to use image and sound transmission. This provision is, of course, applicable also in proceedings before German commercial courts or chambers for international commercial matters.

Pursuant to section 128a (1) of the ZPO, the court may permit the parties, their attorneys-in-fact, and advisers to stay at another location in the course of a hearing for oral argument and to take actions in the proceedings from there. Section 128a (1) of the ZPO does not require the consent of the parties for this. ${ }^{* 19}$ However, it is important to note that the parties are always free to appear in the courtroom physically; a digital hearing cannot be forced upon them. ${ }^{* 20}$ This produces a de facto requirement for consent. Under section 128a (2) of the ZPO, the court may permit a witness, an expert, or a party to the dispute, upon a corresponding application having been filed, to stay at another location in the course of an examination. The images and sound of the hearing or examination shall be broadcast in real time to this location and to the courtroom. However, the broadcast images and sound will not be recorded, either in the cases referred to in paragraph 1 or in those specified in paragraph 2. Unlike the parties', the court's presence must always be

14 Entwurf eines Gesetzes zur Einführung von Kammern für internationale Handelssachen (KfiHG), Bundestagsdrucksache 19/1717, 18 April 2018.

15 Christian Armbrüster, 'Englischsprachige Zivilprozesse vor deutschen Gerichten?' [2011] ZRP 102; Georg Dalitz, 'Justizinitiative Frankfurt - too little too late?' [2017] ZRP 248; Oliver Sieg, Henning Schaloske, and Daniel Kreienkamp, 'In English, please!: Englisch als Gerichtssprache' [2010] AL 309.

16 Clemens Lückemann, ‘§ 185 GVG’ in Richard Zöller (ed), Zivilprozessordnung (33rd edn, Verlag Dr. Otto Schmidt 2020) para 4; Walter Zimmermann, '§ 185 GVG' in Wolfgang Krüger and Thomas Rauscher (eds), Münchener Kommentar zur Zivilprozessordnung mit Gerichtsverfassungsgesetz und Nebengesetzen: Bd. 3 \$ 946-1117, EGZPO, GVG, EGGVG, UKlaG, Internationales und Europäisches Zivilprozessrecht (33. Aufl., C.H. Beck 2017) para 2.

17 Entwurf eines Gesetzes zur Einführung von Kammern für internationale Handelssachen (KfiHG), Bundestagsdrucksache 17/2163, 16 June 2010.

18 Entwurf eines Gesetzes zur Einführung von Kammern für internationale Handelssachen (KfiHG), Bundestagsdrucksache 18/1287, 30 April 2014.

19 Christoph A Kern, ‘§ 128a ZPO’ in Friedrich Stein and Martin Jonas (eds), Kommentar zur Zivilprozessordnung: Bd. $2 \S \S$ 78-147 (23rd edn, Mohr Siebeck 2016) para 11; Astrid Stadler, '§ 128a ZPO' in Hans-Joachim Musielak and Wolfgang Voit (eds), Zivilprozessordnung: mit Gerichtsverfassungsgesetz (17th edn, Verlag Franz Vahlen 2020) para 2.

20 Kern (n 19) para 15; Jörn Fritsche, ‘§ 128a ZPO’ in Wolfgang Krüger and Thomas Rauscher (eds), Münchener Kommentar zur Zivilprozessordnung mit Gerichtsverfassungsgesetz und Nebengesetzen: Bd. 1 \&\& 1-354 (6th edn, C.H. Beck 2020) para 5; Reinhard Greger, ‘§ 128a ZPO’ in Richard Zöller (ed), Zivilprozessordnung (33rd edn, Verlag Dr. Otto Schmidt 2020) para 3. 
maintained in the courtroom, for compliance with the principle of public hearings. ${ }^{* 21}$ For this reason, it is not possible for the judge to participate in online proceedings from his or her home desk. Therefore, fully virtual proceedings are not (yet) possible.

\subsection{France}

As for France, an international division was already established within the Paris Commercial Court in the 1990s. The international division accepts documents and allows hearings in the English language (with the consent of the parties). ${ }^{* 2}$ However, this possibility received little public attention and has rarely been used in practice. ${ }^{*} 3$ In March 2018, the Paris Court of Appeal too established an international chamber (hereinafter referred to as the ICCP-CA), for purposes of complementing the existing first-instance chamber.

\subsubsection{Rules of procedure}

For proceedings before the newly established chamber, the protocol relating to procedural rules applicable to the International Chamber of the Court of Appeal of Paris, or the ICCP-CA protocol, has been created. Under this protocol, the new chamber has jurisdiction to hear appeals of decisions in international commercial and financial disputes (per its Article 1.1). In particular, it will rule on appeals arising from judgements in first instance by the pre-existing International Division of the Paris Commercial Court (per Article 1.3).

The ICCP-CA is composed of judges with expertise in international commerce and the necessary English-language skills. By default, the hearing is held in French, but the parties, witnesses, experts, and foreign lawyers may express themselves in English (under Article 2.4 of the ICCP-CA protocol). In this case, however, simultaneous translation is required (per Article 3.3). In addition, the chamber accepts documents in English without translation (see the ICCP-CA protocol's Article 2.2). While the judgements will be given in French, they may be accompanied by a translation into English by a sworn translator (under Article 7 of the protocol). Regrettably, the numbers of cases heard by the chamber have not been published, thus far. Seventeen cases are reported to have been filed by December 2018. ${ }^{* 24}$

\subsubsection{The possibility of online hearings}

The French Code of Civil Procedure (Code de procédure civile) does not provide for the use of videoconferencing in civil proceedings. However, Article L111-12 of the Code of Judicial Organisation (Code de l'organisation judiciaire) allows court hearings to take place in several courtrooms directly connected by an audiovisual means of telecommunication that guarantees the confidentiality of the transmission. One or more of these courtrooms may be outside the jurisdiction of the court seised. Accordingly, it is not possible, for example, to conduct a witness examination by means of videoconferencing beyond the premises of a court.

\subsection{The Netherlands}

In the Netherlands (more precisely, in Amsterdam), the Netherlands Commercial Court opened its doors in January 2019. This court is composed of the first-instance NCC District Court (hereinafter referred to as the NCC) as a specialised chamber of the Amsterdam District Court (the Rechtbank), and the NCC Court of Appeal (hereinafter referred to as the NCCA) as a special chamber of the Amsterdam Court of Appeal (the Gerechtshof).

21 Kern (n 19) para 18; Stadler (n 19) para 2.

22 Emmanuel Jeuland, 'The International Division of the Paris Commercial Court' [2016] TCR 143, 144. - DOI: https://doi. org/10.5553/tcr/092986492016024004010.

23 For reasons, see Jeuland (n 22); see also Alexandre Biard, 'International Commercial Courts in France: Innovation without Revolution?' [2019] Erasmus Law Review 24, 27. - DOI: https://doi.org/10.5553/elr.000111.

24 Biard (n 23) 25. 


\subsubsection{Rules of procedure}

A special set of rules was created for proceedings before the NCC and also the NCCA, the Rules of Procedure of the Netherlands Commercial Court (NCC Rules). Article 1.3 of the NCC Rules defines the competence of the NCC and the NCCA. Since the NCC is a chamber of the Amsterdam District Court, its jurisdiction must therefore be established first. This can be done either by the parties concluding an (international) choice-ofcourt agreement in favour of the Amsterdam District Court or, in the absence of a jurisdiction agreement, the Amsterdam District Court having jurisdiction for other reasons. In order to establish the jurisdiction of the NCC within the Amsterdam District Court, there must be a civil or commercial dispute of an international nature. Finally, the parties must agree in writing to be heard in English before the NCC. The NCCA is responsible for appeals against judgements of the NCC of first instance.

Article 2.1 of the NCC Rules states that the language of the proceedings is English. However, not only are the proceedings conducted in the English language, but also, at least in principle, the judgements will be provided in the English language. The proceedings take place before a panel of judges selected for their broad base of expertise in international commercial litigation and their English-language skills. ${ }^{* 25}$

Finally, the NCC is to be self-supporting, which is why the NCC charges a court fee that is higher than that for standard civil proceedings. ${ }^{*}{ }^{26}$ Only six weeks after its opening, the first case was heard before the NCC, and just a few days later the first judgement was pronounced. So far, the court has heard ten cases. ${ }^{* 27}$

\subsubsection{The possibility of online hearings}

There are no specific provisions in the Dutch Code of Civil Procedure (Wetboek van Burgerlijke Rechtsvordering) providing for the use of videoconferences. The NCC Rules, however, enable the use of modern communications technology in proceedings before the NCC and the NCCA. Pursuant to Article 3.2.2, the court may direct that communication with the court be done by telephone, videoconferencing, or any other suitable means. The court may also direct that an audio or video recording be made by or on behalf of the court (per Article 7.7.2). In addition, Article 7.8 addresses combined hearings with a closely connected foreign case, which may be held via videoconferencing or any other suitable means.

\subsection{The Standing International Forum of Commercial Courts}

In 2017, Lord Thomas (former Lord Chief Justice of England and Wales) initiated the establishment of the Standing International Forum of Commercial Courts. The forum aims to promote co-operation and collaboration among commercial courts around the world. The reports from the first two meetings in London and New York attest to an increased need for the use of new technologies in proceedings before commercial courts. ${ }^{*} 8$ This accentuates even further the growing need for increased use of modern communications technology not only in Europe but worldwide.

\section{Recent developments related to the COVID-19 pandemic}

The coronavirus pandemic has had an impact on all aspects of private and public life both, not least on the work of the courts. Infection control and health-safety measures require a radical reduction in personal contacts. Most clearly from the end of March 2020, court hearings had to be postponed, and time limits

25 Eddy Bauw, 'Commercial Litigation in Europe in Transformation: The Case of the Netherlands Commercial Court' [2019] Erasmus Law Review 15, 17. - DOI: https://doi.org/10.5553/elr.000110.

26 Ibid; Harriët Schelhaas, 'The Brand New Netherlands Commercial Court: A Positive Development?' in Xandra Kramer and John Sorabji (eds), International Business Courts: A European and Global Perspective (Eleven International Publishing 2019) 55-56.

27 'Judgments: Netherlands Commercial Court' < www.rechtspraak.nl/English/NCC/Pages/judgments.aspx > accessed 15 July 2021.

28 Standing International Forum of Commercial Courts, 'Report on the first meeting, London, 4-5 May 2017'< http://sifocc. prod.wp.dsd.io/app/uploads/2018/03/First_SIFOCC_Report_-_FINAL.pdf > accessed 15 July 2021; Standing International Forum of Commercial Courts, 'Report of the Second Meeting, New York, 27-28 September 2018' <http://sifocc.prod.wp.dsd. io/app/uploads/2019/02/Report-of-the-Second-SIFoCC-Meeting-New-York-2018.pdf> accessed 15 July 2021. 
needed to be extended. This could not, of course, be a long-term solution. Against this background, the possibility of conducting online proceedings has never been more relevant.

\subsection{Germany}

Ever since 2002, section 128a of the ZPO (which has been in force in its current version since 2013) has allowed for the possibility of online hearings. So far, however, the relevant provision has received little attention. ${ }^{* 2}$ This has now changed, on account of the coronavirus pandemic. Since March 2020, the possibility of video hearings under section 128a of the ZPO has been discussed extensively in law journals and blogs. ${ }^{*} 0$

In practice, however, the opportunity of video hearings is still not exercised extensively. The experience with online hearings varies significantly between district courts. ${ }^{*}{ }^{31}$ While online hearings have already been conducted in remarkable numbers at some district courts, other district courts have not yet recorded a single online hearing. ${ }^{*}{ }^{32}$ The reasons for this are manifold and cannot be ascertained with absolute certainty. One factor is most assuredly the fact that many courts simply lack the technical equipment necessary for online hearings. ${ }^{*} 33$ Moreover, there are cases in which the court or the lawyers are unwilling to conduct online proceedings - complaints have been raised from both the judiciary and the legal profession. ${ }^{*}{ }^{34}$ Finally, not all proceedings are suitable for video hearings - for example, in cases wherein personal impressions are essential in the context of a witness examination. ${ }^{*} 35$ This issue notwithstanding, a phenomenon of increasing awareness of the need for online hearings can be observed, which one hopes will continue after the pandemic.

\subsection{France}

Because the French Code of Civil Procedure does not make any provisions for conducting proceedings by means of video transmission, such a provision had to be created in the context of the COVID-19 pandemic. The French Government issued, among other orders, an order adapting the rules applicable to the judiciary ruling in non-criminal matters. ${ }^{*}{ }^{36}$ Article 7 gives the judge the option of determining that the hearing or examination shall be held via a means of audiovisual telecommunication that makes it possible to verify the identity of the persons participating in it and guarantees the quality of the transmission and the confidentiality of the exchanges between the parties and their lawyers. In the event of the technical or material impossibility to employ such a means, the judge may decide to hear the parties and their lawyers, or the person to be examined, by any means of electronic communication, including telephone, which makes it possible to be assured of their identity and guarantee the quality of transmission and the confidentiality of exchanges.

29 Michaela Balke, Thomas Liebscher, and Richard Helwig, 'Die Coronakrise und der digitale Zivilprozess: Wie die Videokonferenz den Zivilprozess überleben lässt' [2020] AnwBl 366, 367; Philipp Reuß, 'Die digitale Verhandlung im deutschen Zivilprozessrecht' [2020] JZ 1135. - DOI: https://doi.org/10.1628/jz-2020-0360; Benedikt Windau, 'Die Verhandlung im Wege der Bild- und Tonübertragung: Praxisorientierte Überlegungen zu Gegenwartsproblemen des Zivilprozessrechts' [2020] NJW 2753.

30 Martin Fries, 'Die vollvirtuelle Verhandlung - Quo vadis, § 128a ZPO ?' [2020] GVRZ 27. - DOI: https://doi.org/10.9785/ gvrz-2020-030217; Reinhard Greger, 'Der Zivilprozess in Zeiten der Corona-Pandemie - und danach' [2020] MDR 509. DOI: https://doi.org/10.9785/mdtr-2020-740903; Reto Mantz and Jan Spoenle, 'Corona-Pandemie: Die Verhandlung per Videokonferenz nach § 128a ZPO als Alternative zur Präsenzverhandlung' [2020] MDR 637. - DOI: https://doi.org/10.9785/ mdtr-2020-741103; Reuß (n 29); Windau (n 29).

31 Mantz and Spoenle (n 30) 641-43; Annelie Kaufmann, 'Gerichte wollen, Anwälte nicht - oder andersrum?' (Legal Tribune Online, 16 December 2020) <www.lto.de/recht/justiz/j/video-verhandlungen-128a-zpo-online-verfahren-gerichte-anwaelteantrag-abgelehnt-ermessen-corona/> accessed 15 July 2021.

32 Kaufmann (n 31).

33 Balke, Liebscher, and Helwig (n 29) 368; Fries (n 30) para 4; Greger (n 30) 513; Reuß (n 29).

34 Kaufmann (n 31).

35 Fritsche (n 20) para 14; Mantz and Spoenle (n 30) 641; Reuß (n 29) 1137; Windau (n 29) 2756.

36 Ordonnance $\mathrm{n}^{\circ}$ 2020-304 du 25 mars 2020 portant adaptation des règles applicables aux juridictions de l'ordre judiciaire statuant en matière non pénale et aux contrats de syndic de copropriété. 


\subsection{The Netherlands}

The Dutch Government adopted a general regulation on the settlement of cases by the judiciary during the pandemic. ${ }^{*} 37$ Pursuant to its Article 1.2.1, the court or tribunal shall determine whether a hearing is to take place with the parties and other participants in the proceedings physically present or, instead, online. If it is not possible to hear the case physically or online, the hearing may take place by telephone. Also, it is possible to combine these types of proceedings (physical, online, and by telephone).

For proceedings before the Netherlands Commercial Court, hearings may, wherever this is possible and appropriate, be held electronically, via a conference call, or with videoconferencing equipment. ${ }^{*}{ }^{8}$ The NCC held its first public hearing using videoconference equipment on 10 April 2020. ${ }^{*} 39$ Any member of the public wishing to attend a videoconference hearing must register via e-mail to obtain a login link. ${ }^{*} 40$ The NCC website provides a detailed manual for attending an NCC Skype hearing. ${ }^{*}{ }^{4}$

\section{Cross-border online hearings}

The measures presented above are limited to the national level, however. If the parties, the witnesses, or experts to be heard are located in a different state than the court, evidence cannot simply be taken abroad. This is because the conducting of an oral hearing and the taking of evidence are fundamentally sovereign acts. ${ }^{*}{ }^{2}$ For this reason, a court wishing to perform a sovereign act abroad must - though there are exceptions - rely on the use of mutual legal assistance involving the other state. ${ }^{*} 43$ The extent to which the use of videoconferencing technologies is possible in this context is examined in the discussion that follows. ${ }^{*} 4$

\subsection{The Taking of Evidence Regulation ${ }^{*} 45$}

Within the European Union, the Regulation on cooperation between the courts of the member states in the taking of evidence in civil or commercial matters, or the Taking of Evidence Regulation, applies. This instrument improves and simplifies the co-operation between the courts in the cross-border taking of evidence within the member states for the purpose of the proper functioning of the internal market (see its Recital 2).

The regulation does not contain a definition for 'taking of evidence'. In particular, it is not clear whether the hearing of parties too falls under this term and, thereby, within the scope of the regulation. The latter ambiguity results from the fact that the legal systems of the member states are structured very differently in this respect. ${ }^{*} 6$ For example, German law strictly differentiates between the position of a witness and the position of a party (the party to a legal dispute can never be a witness in this context), whereas Dutch law

37 Tijdelijke algemene regeling zaaksbehandeling Rechtspraak.

38 'COVID-19: NCC is open for business, but restrictions apply’ (25 March 2020) <www.rechtspraak.nl/English/NCC/news/ Pages/COVID19-NCC-is-open-for-business-but-restrictions-apply.aspx> accessed 15 July 2021.

39 'The Netherlands Commercial Court and COVID-19: case management, videoconference hearings and eNCC' (27 May 2020) $<$ www.rechtspraak.nl/English/NCC/news/Pages/The-Netherlands-Commercial-Court-and-COVID19-case-managementvideoconference-hearings-and-eNCC.aspx> accessed 15 July 2021.

40 'COVID-19: NCC is open for business, but restrictions apply' (n 38).

41 'Manual for attending an NCC Skype hearing' <www.rechtspraak.nl/SiteCollectionDocuments/manual-for-attending-anNCC-Skype-hearing.pdf> accessed 15 July 2021.

42 Reinhold Geimer, Internationales Zivilprozessrecht (8th edn, Verlag Dr. Otto Schmidt 2020) para 120, 442. - DOI: https:// doi.org/10.9785/9783504386566; Heinrich Nagel and Peter Gottwald, Internationales Zivilprozessrecht (8th edn, Verlag Dr. Otto Schmidt 2020) para 7.35. - DOI: https://doi.org/10.9785/9783504387099.

43 Haimo Schack, Internationales Zivilverfahrensrecht: mit internationalem Insolvenzrecht und Schiedsverfahrensrecht (7th edn, C.H. Beck 2017) para 797. - DOI: https://doi.org/10.17104/9783406746437; Geimer (n 42) paras 120 and 442.

44 See General Secretariat of the Counsel, 'Guide on videoconferencing in cross-border proceedings' (2013) <https://op.europa. eu/en/publication-detail/-/publication/bbdbd7f4-7da8-479d-ad83-0b56463d8e32> accessed 15 July 2021.

45 Council Regulation (EC) 1206/2001 of 28 May 2001 on cooperation between the courts of the Member States in the taking of evidence in civil or commercial matters [2001] OJ L174/1.

46 See Jan von Hein, 'Art. 1 EuBVO’ in Thomas Rauscher (ed), Europäisches Zivilprozess- und Kollisionsrecht: Bd. 2 EGVollstrTitelVO - EG-MahnVO - Eu-KPfVO - HProrog ̈̈bk 2005 - EG-ZustVO 2007 - EG-BewVO - EG-InsVO (4th edn, Verlag Dr. Otto Schmidt 2015) para 15. 
recognises a party as a valid witness. ${ }^{*} 47$ Against this background, the term 'taking of evidence' should be defined in a broad sense and encompass the hearing of parties. ${ }^{*} 48$

The Taking of Evidence Regulation distinguishes between two forms of request for cross-border taking of evidence in its Article 1 (1): the court of a Member State may either request the competent court of another Member State to take evidence (per Article 10 et seq.) or request to take evidence directly in another Member State (under Article 17). In cases wherein evidence is taken by the requested court, the parties and, if any, their representatives, have the right to be present at the performance of the taking of evidence by the requested court, if this is provided for by the law of the requesting court's Member State (see Article 11). The same applies to the presence and participation of representatives of the requesting court (including members of the judicial personnel designated for this purpose by said court), under Article 12. Where necessary, in executing a request the appropriate coercive measures shall be applied by the court that is subject to the request (per Article 13). The request may be refused only for the reasons set forth in Article 14 - e.g. because there exists a right to refuse to give evidence.

In contrast, the direct taking of evidence by the requesting court is unlike taking of evidence by the requested court in that it may take place only if it can be performed on a voluntary basis, without the need for coercive measures (see Article 17 (2)).

Both forms of taking evidence may be carried out using communication technology, such as videoconferences and teleconferences (see Article 10 (4) and Article 17 (4), respectively). However, while a request for the taking of evidence by means of communication technology shall be complied with in the context of the taking of evidence by the court requested to do so unless this is incompatible with the law of the Member State of the requested court or by reason of major practical difficulties, such use is only to be encouraged in the context of the direct taking of evidence by the requesting court. The use of videoconferencing in the context of the direct taking of evidence could hardly be formulated in a more non-binding way. Finally, difficulties may arise from the fact that not all civil courts in each Member State have the necessary equipment in place for conducting videoconferences. ${ }^{*} 49$ It remains to be seen whether this will change in the wake of the coronavirus pandemic.

\subsection{The Hague Convention on the Taking of Evidence Abroad}

For the taking of evidence outside the European Union, the Hague Convention on the Taking of Evidence Abroad applies, provided that both the requesting state and the state receiving the request are signatories to the convention. Although the convention does not make any provisions for the taking of evidence by means of videoconferencing, examination by videoconference could be interpreted as a special form of execution of a request for legal assistance within the meaning of Article 9 (2). ${ }^{*} 50$

\subsection{The recast of the Taking of Evidence Regulation}

In November 2020, the Taking of Evidence Regulation was recast, and it will apply in its new form from 1 July 2022. ${ }^{*}{ }^{1}$ The aim in this was to improve the effectiveness and speed of judicial proceedings by simplifying and streamlining the mechanisms for co-operation in the taking of evidence in cross-border proceed-

47 Gerhard Wagner, 'Europäisches Beweisrecht - Prozessrechtsharmonisierung durch Schiedsgerichte' [2001] ZEuP 441, 485 and 494.

48 Hans-Jürgen Ahrens, Der Beweis im Zivilprozess (1st edn, Verlag Dr. Otto Schmidt 2015) ch 58, para 43, and ch 59, para 44. - DOI: https://doi.org/10.9785/ovs.9783504384395; von Hein (n 46) para 17.

49 Commission, 'Report from the Commission to the Council, the European Parliament and the European Economic and Social Committee on the application of the Council Regulation (EC) 1206/2001 of 28 May 2001 on cooperation between the courts of the Member States in the taking of evidence in civil or commercial matters' COM (2007) 769 final, 4.

50 The Hague Conference on Private International Law - HCCH Permanent Bureau, 'Guide to Good Practice on the Use of Video-Link under the Evidence Convention' (2020) para 53 <https://assets.hcch.net/docs/569cfb46-9bb2-45e0-b240ec02645ac20d.pdf> accessed 15 July 2021; see also Christian Berger, ‘Anhang zu § 363 ZPO’ in Friedrich Stein and Martin Jonas (eds), Kommentar zur Zivilprozessordnung: Bd. $5 \S \S 328-510 c$ (23rd edn, Mohr Siebeck 2015) para 55; Stadler (n 19) para 8.

51 Regulation (EU) 2020/1783 of the European Parliament and of the Council of 25 November 2020 on cooperation between the courts of the Member States in the taking of evidence in civil or commercial matters [2020] OJ L405/1. 
ings, through, inter alia, the digitalisation of procedures (see Recital 3). Accordingly, the recast focuses on innovations in modern communication technology, such as videoconferencing (see Recital 21 et seq.).

The possibility of the requested court using communications technology in the taking of evidence has remained unchanged (see Article 12 (4)). However, there is a new provision for the context of the direct taking of evidence by the requesting court. While Article 17 (4) of the (still) current version of the regulation provides for only encouragement of the use of communications technology, Article 20 of the recast now explicitly deals with the direct taking of evidence via videoconferencing or other distance communications technology: Where evidence is to be taken by examining a person who is present in another Member State, and the court requests the taking of evidence directly, that court shall take the evidence by using videoconferencing or other distance communications technology, provided that such technology is available to the court and the court considers the use of such technology to be appropriate in the specific circumstances of the case. The request is made via a standard form, which can be found in Annex I. Per Article 7, requests shall be transmitted through a new decentralised IT system with due respect for fundamental rights and freedoms.

Since the taking of evidence by videoconferencing is a form of direct taking of evidence, its requirements are governed by Article 19. This means that the request for the direct taking of evidence may only be refused on only those grounds laid out in Article 19 (7). The condition must also apply to the direct taking of evidence by videoconferencing under Article 20. The recast thus strengthens the use of communication technologies.

Nevertheless, the recast of the regulation does not change the fact that some member states still lack the necessary technical equipment. Against this background, it remains open to critical questioning whether the recast will actually lead to expanded use of video technologies in the context of cross-border taking of evidence.

\subsection{Use of videoconferencing outside mutual legal assistance}

There is controversy over whether evidence may be taken by way of videoconference even outside the arena of mutual legal assistance - in particular, without recourse to the procedure laid down in Article 17 of the Taking of Evidence Regulation. This depends on whether that regulation is exhaustive in nature with regard to video examinations.

The existence of Article 17 (4) especially could speak to an exhaustive nature of the regulation with regard to conducting videoconferences in the context of the taking of evidence, because otherwise there would be no need for a provision under the Taking of Evidence Regulation. ${ }^{*} 52$ Accordingly, video examination of a person residing in another Member State would qualify as taking of evidence within the meaning employed by the regulation. ${ }^{*} 53$

In contrast, a cross-border video examination could be considered to be mere gathering of evidence, for which the Taking of Evidence Regulation does not claim any exhaustive effect. ${ }^{*} 4$ Although Article 17 (4) of the regulation makes provision for the use of communication technologies, such as videoconferencing, this provision states merely that the use of these technologies is encouraged. ${ }^{*} 55$

This view is strongly supported by two decisions of the European Court of Justice (ECJ), which argue against the exclusivity of the Taking of Evidence Regulation. In the first of these, the ECJ ruled that the regulation applies as a general rule only if the court of a Member State decides to take evidence in accordance with one of the two methods provided for by said regulation, in which case it is required to follow the procedures related to those methods. ${ }^{*}{ }^{6}$ Against this background, the ECJ concluded that the competent court of a Member State has the power to summon as a witness a party residing in another Member State and to hear that party in accordance with the law of the Member State in which that court is

52 Burkhard Hess, 'Kommunikation im europäischen Zivilprozess: Praktische Erfahrungen mit der justiziellen Kooperation in grenzüberschreitenden Zivilsachen' [2011] AnwBl 321, 324; Schack (n 43) para 807.

53 Götz Schulze, 'Dialogische Beweisaufnahmen im internationalen Rechtshilfeverkehr: Beweisaufnahmen im Ausland durch und im Beisein des Prozessgerichts' [2001] IPRax 527, 529; Astrid Stadler, 'Der Zivilprozeß und neue Formen der Informationstechnik' (2002) 115 ZZP 413, 441; Hendrik Schultzky, 'Videokonferenzen im Zivilprozess' [2003] NJW 313, 314; Stadler (n 19) para 8.

54 Oliver L Knöfel, 'Recht eines "Justizflüchtlings" auf grenzüberschreitende Videovernehmung im europäischen Zivilprozess' [2006] RIW 301, 304; Peter Mankowski, 'Auslandszeugen, Prozesstaktik, Videovernehmung und weitere Optionen' [2014] RIW 397, 400.

55 Knöfel (n 54) 304.

56 Case C-170/11 Maurice Robert Josse Marie Ghislain Lippens and Others $v$ Hendrikus Cornelis Kortekaas and Others [2012] ECLI:EU:C:2012:540, para 28. 
situated. ${ }^{*} 7$ The outcome that follows naturally from this decision is to be agreed with, although the significance of the decision itself is limited: The parties' procedural obligation to co-operate is generally accepted (at least if international jurisdiction is given). ${ }^{*} 58$

With regard to the conduct of videoconferences, the second judgement is even more interesting. It pertains to the taking of evidence by an expert in the territory of another Member State. In this context, the ECJ ruled that a court wishing to order such an expert investigation is not necessarily required to have recourse to the method of taking evidence laid down in Article 1 (1) (b) and Article 17 of the Taking of Evidence Regulation. ${ }^{*} 59$ However, the ECJ stated, where the investigation affects the powers of the Member State in which it takes place, the method of taking evidence laid down in those portions of the regulation is the only means to enable a Member State's court to carry out such an investigation directly in another Member State. ${ }^{*} 60$

From the impression given by the case law outlined above, one could argue that the Taking of Evidence Regulation is not exclusive with regard also to the examination of a person located in a Member State other than that of the court by means of videoconferencing. ${ }^{*}{ }^{* 1}$ If Article 17 (3)'s explicit mention of the taking of evidence by an expert does not have a restrictive effect, the same probably must apply to the mention of the taking of evidence by videoconferencing in Article 17 (4). ${ }^{* 62}$

This view can hardly be supported under the recast of the regulation, however. As has already been pointed out, the recast not only encourages the use of videoconferencing technologies (as the current version does) but explicitly includes video examination in the catalogue of measures falling under the regulation by inserting Article 20. ${ }^{* 63}$ The Article clarifies that if a court intends to take evidence by examining a person who is present in another Member State, that court shall take evidence using videoconferencing. The use of videoconferencing is, therefore, to be regarded in future as the method of choice for the direct taking of evidence.

Against this background, it is no longer possible to consider examining a person by means of videoconferencing to be a mere evidence-gathering measure. ${ }^{*} 64$ Rather, it constitutes a method of taking evidence and, therefore, falls within the scope of the Taking of Evidence Regulation. In this respect, the regulation must be regarded as exhaustive. Nevertheless, final binding clarification by the ECJ with regard to the video examination of a person who is present in another Member State would be desirable.

As much as the recast is intended to simplify the cross-border taking of evidence through increased use of video technologies, it clarifies that cross-border videoconferencing is possible only in a manner compliant with the procedure provided for by the regulation. This is regrettable, as the use of mutual legal assistance is always time-consuming. The attractiveness of the presented commercial courts and chambers as a forum for the efficient and speedy resolution of disputes would therefore benefit from making cross-border videoconferencing as easy as possible.

\section{Conclusion}

The extent to which communication technology is exploited for carrying out online hearings varies greatly among the various international commercial courts and chambers. Since the COVID-19 pandemic reached crisis proportions, increased demand for the use of videoconferencing technologies could be observed in all three jurisdictions (Germany, the Netherlands and France). One would hope that the tendency toward increased digitalisation continues after the pandemic has subsided; however, it seems rather doubtful whether the recast of the Taking of Evidence Regulation will actually contribute to this.

57 Ibid para 37

58 von Hein (n 46) para 32; Schack (n 43) para 794; Geimer (n 42) para 431.

59 Case C-332/11 ProRail BV v Xpedys NV and Others [2013] ECLI:EU:C:2013:87, para 49.

60 Ibid para $47 \mathrm{ff}$.

61 Stefan Huber, 'Der optionale Charakter der Europäischen Beweisaufnahmeverordnung' [2014] ZEuP 642, 660; von Hein (n 46) para 22; Thomas Rauscher, 'Art. 1 EuBVO' in Wolfgang Krüger and Thomas Rauscher (eds), Münchener Kommentar zur Zivilprozessordnung mit Gerichtsverfassungsgesetz und Nebengesetzen: Bd. 3 §§ 946-1117, EGZPO, GVG, EGGVG, UKlaG, Internationales und Europäisches Zivilprozessrecht (5th edn, C.H. Beck 2017) para 12; Karl Kreuzer, Rolf Wagner, and Robert Häcker, 'Q. III. Allgemeine Verfahrensfragen' in Manfred A Dauses and Markus Ludwigs (eds), Handbuch des EU-Wirtschaftsrechts (50th edn, C.H. Beck 2020) para 47.

62 Huber (n 61) 660-61.

63 Oliver L Knöfel, ‘Der Kommissionsvorschlag von 2018 zur Änderung der Europäischen Beweisaufnahmeverordnung' [2018] RIW 712, 715.

64 See Knöfel (n 63) 715 with regard to the Commission's proposal (COM (2018) 378 final). 